\title{
The Investigation of Relationship Between the Satisfaction Level and Perceived Organizational Support of Human Resources Management Practices in Sport Organizations
}

\author{
Ramazan Topuz ${ }^{1}$, Hakan Salim Çağlayan ${ }^{1}$ \\ ${ }^{1}$ Selçuk University, Faculty of Sport Sciences, Konya, Turkey \\ Correspondence: Ramazan Topuz, Selçuk University, Faculty of Sport Sciences, Konya, Turkey.
}

Received: August 22, 2019

doi:10.11114/jets.v7i10.4466
Accepted: September 18, 2019 Online Published: September 19, 2019

URL: https://doi.org/10.11114/jets.v7i10.4466

\begin{abstract}
The input and output of all sports organizations is human; therefore, it is considered that the human resources management practices that are applied in sports organizations have a special importance. In the light of this idea, satisfaction level and perceived organizational support from human resources management in sport organizations were examined in terms of various variables. The universe of the research is composed of the individulas who work in various stages of provincial directorates of sports in Turkey and the sample group consists of 321 people, 223 males and 98 females, selected randomly from these provincial directorates. In the study, the satisfaction scale of Human Resources Management practices developed by Gürbüz and Bekmezci (2012) by using the scales in the literature and Perceived Organizational Support Scale developed by Eisenberger et al., (1986) were used. As a result; In body of the literature, it is seen that the studies on human resources management practices and perceived organizational support in sports organizations are quite limited; There is a significant difference in the satisfaction level from hrm of the employees working in the provincial directorates of sports according to gender, working year, staff type, age category and education levels and there weren't significant difference in perceived organizational support dimension according to gender, working year, staff type, age category but there were significant differences in educational level; There were significant, moderate $(\mathrm{R}=0.3-0.7)$ and positive relationships between the two scales in terms of all variables.
\end{abstract}

Keywords: sports organization, human resource management practices, perceived organizational support

\section{Introduction}

Sport is both one of the most important social forces of the age at the international level and it is a social institution which comes down to earth and roots there at the national level. The first organizational form of sports is the public legal entity within the state hierarchy, the second organizational form is the physical education and sport collectives, clubs and clusters, which are independent, voluntary and aggregate-social (Fişek, 1998). As a result of constantly developing and changing needs in societies, new organizations have been established to organize services in different fields. Sports organizations are one of them (Bilir, 2005).

Organizations are established by poeple and for them. The expansion of the fields of activity of the organizations and accordingly the increase in the number of people working begin causing problems to increase. As a result of this, the management of human resources in organizations has become an important issue. Therefore, organizations have started to establish units for the management of personnel and human resources in order to use human resources effectively, to realize their objectives and to carry out organizational activities in an order and discipline (Buluç, 1998). The human factor is the greatest competitive basis for organizations. Organizations that can get the most efficency from human factor by using it appropriately will be the winner in the competition (Çavuş \& Develi, 2015). The success of sports organizations depends on the ability to constantly adapt itself and its structure to the changing conditions and the level of performance of the employees. Accurate evaluation of employee performance and the use of evaluation results in human resources planning will have led to steps to resolve many of the administrative problems (Oğuz, 2009, Akt: Ilgar, 2014).

Human resources management is a function of record keeping in organizations, training, development, motivation and labor provision activities. Human resources management is defined as a set of activities aimed at providing, developing and maintaining the most effective workforce for the organization (Mutlu, 2016). Human resource management 
practices can motivate employees by influencing them in line with the objectives of the organization and ensure the development of business performance (Huselid, 1995; Pate and Beaumont, 2006).

Having ability to hitting the success peak of all organizations, whether public or private sector, depends on the correct determination of their strategies and their implementation of the system within the scope of this strategy. Human resources should be emphasized in order for organizations to plan the appfropriate strategy (Demir, 2013) and undoubtedly, the first thing to keep in mind is the development of human resources (Berk, 2017).

A separate management approach in itself, in other words, the importance of human resources management has emerged in the most efficient use of manpower (Dolaşır et al., 2002). Human resources management aims to make individuals work more effectively and efficiently, while also aiming for employees who are happy and have highly work satisfaction (Çolak, 2017). The following functions of human resources can be used in achieving the specified objectives: 1-Identifying the HRM policy, 2-Personnel organization, 3-Personnel planning and procurement, 4-Performance management, 5-Wage management, 6-Education management, 7-Motivation management, 8-Quality management, 9-Personal affairs (Koca, 2008). In addition, human resources management applications include rewarding, wage system, education system, performance evaluation system, career system, communication / participation and empowerment processes with the employee (Gürbüz \& Bekmezci, 2012).

Human resources management plays an effective role in achieving the goals of the organization by reinforcing individual performance through the policies and practices it implements, and processing the manpower in the organization with eachother synchoronously (Kuzutürk, 2016). As a social and emotional entity, a human wants to be appreciated, to be respected, needs to provided such as having a gradual status in workplace in return for his/her work; this is where organizational support comes in.

The fact that the employee feels confident in the organization he works for and perceives that he is supported by the organization causes him to take a more positive attitude towards the organization and see himself as a part of the organization. At this point, organizational support is a concept that examines the relationship between the employer and the employee and reveals the employee's perception of the institution (Nayır, 2014). According to Rhoades and Eisenberger (2002), there are three main factors that generate the perception of organizational support: these are organizational justice, supervisory support, organizational rewards and positive working conditions. Organizational support is all of the activities of organizations about how much they care about the happiness of their employees and how much they value their contributions. Among employees who have high perception of support by their organizations, increasing in intra-role and extra-role performance and decreasing in behaviours such as being late for work, leaving work, slowing down work and high job satisfaction, decreasing psychological and psychosomatic disorders and some useful results such as engaging emerge in the terms of both employees and organizations (Üren \& Çorbacioğlu, 2012; Turgut, 2014). Perceived organizational support is that employees feel safe and feel the presence of the organization behind them. Employees, who always feel the support of the organization at their side, will be more attached to their jobs and will not consider leaving the workplace (Özdevecioğlu, 2003). Perceived organizational support by employees increases the tendency of employees to make more efforts to achieve organizational goals by enabling them to participate more (Eisenberger et al., 1986). Organ in an organizational support must support their employees who need respect; commitment, emotional support and high needs. Thus, an additional obligation is required for the employees to work hard on behalf of the organization whose strong socio-emotional needs are provided (Armeli et al., 1998).

The idea of perceived organizational support has become very important over time; According to this idea, if employers want their employees' commitment and loyalty to their organizations, they have to focus on the needs of their employees (Hakeem \& Nisa, 2016). Perceived organizational support enhances the positive atmosphere by contributing to employees' sense of competence and value (Nugroho, 2017; Krishnan \& Mary, 2012).

The input and output of all sports organizations is human; therefore, it is considered that the human resources management practices applied in sports organizations have a special importance. In the light of this idea, the research was conducted in order to examine the satisfaction level of human resources management and perceived organizational support in sports organizations in terms of various variables.

\section{Method}

\subsection{Research Model}

In this study, a causal comparative research model which is one of the quantitative research models was used.

\subsection{Sample}

The universe of the research is composed of the individulas who work in various stages of provincial directorates of sports in Turkey and the sample group consists of 321 people, 223 males and 98 females, selected randomly from these provincial directorates. 


\subsection{Data Collection Tools}

Two separate scales were used in the study. The first scale is the satisfaction scale of Human Resources Management applications developed by Gürbüz \& Bekmezci (2012) by taking advantage of the scales in the literature. In the scale; There are total 5 sub-dimensions and 22 articles named in the form of Rewarding (Articles 1 and 5), Wage System (Articles 6 and 9), Career System (Articles 10 and 14), Training Practices and Performance Evaluation (Articles 15 and 19) and Communication with Employees (Articles 20 and 22). Cronbach's alpha reliability coefficient for the whole scale was calculated as 90. In this study, Cronbachalfa was found to be 91 . The second scale used was Perceived Organizational Support Scale. The 8-article short version of the 36-article scale developed by Eisenberger et al., (1986) to measure the perception of organizational support was used. The answers were obtained with a 5-point Likert scale (1 = ceryainly disagree, 5 = certainly agree). Questions two, three, five and seven are reverse coded. The Cronbach's alpha reliability coefficient of the perceived organizational support scale is 0.89 (Sökmen et al., 2015). In this study, Cronbach's alpha value of the scale was found to be 83 .

\subsection{Data Analysis}

Statistical package program was used in the analysis of the data used in the research. Data were sweetened by producing descriptive statistics. The t test was used for paired comparisons, One-WayAnova was used for multiple comparisons and Post Hoc-Bonferroni test was used to determine the source of difference.

\section{Findings}

Table 1. The Variances of the Satisfaction Level of HRM Applications According to Gender Variable

\begin{tabular}{|c|c|c|c|c|c|c|c|c|c|c|c|c|}
\hline \multirow[t]{2}{*}{$\begin{array}{l}\text { Gende } \\
\mathrm{r}\end{array}$} & \multirow[t]{2}{*}{$\mathrm{N}$} & \multirow[t]{2}{*}{$\%$} & \multicolumn{2}{|c|}{ Rewarding } & \multicolumn{2}{|c|}{ Wage System } & \multicolumn{2}{|c|}{$\begin{array}{l}\text { Career } \\
\text { System }\end{array}$} & \multicolumn{2}{|c|}{$\begin{array}{c}\text { Training } \\
\text { Practices and } \\
\text { Performance }\end{array}$} & \multicolumn{2}{|c|}{$\begin{array}{c}\text { Communicatio } \\
\text { n with } \\
\text { Employee }\end{array}$} \\
\hline & & & $\overline{\mathrm{x}}$ & Ss & $\overline{\mathrm{x}}$ & Ss & $\overline{\mathrm{X}}$ & SS & $\overline{\mathrm{x}}$ & Ss & $\overline{\mathrm{x}}$ & Ss \\
\hline \multirow{2}{*}{$\begin{array}{l}\text { Femal } \\
\mathrm{e}\end{array}$} & \multirow{2}{*}{98} & 30. & 2,2 & ,96 & 2,2 & ,87 & 2,5 & ,94 & 2,8 & 67 & 2,2 & 1,0 \\
\hline & & 5 & 8 & 0 & 9 & 7 & 6 & 1 & 0 & 6 & 3 & 0 \\
\hline \multirow{2}{*}{ Male } & 22 & 69. & 2,2 & ,98 & 2,5 & 90 & 2,6 &, 87 & 2,9 & 67 & 2,3 & 1,0 \\
\hline & 3 & 5 & 5 & 2 & 1 & 7 & 9 & 5 & 2 & 0 & 9 & 7 \\
\hline \multirow[t]{3}{*}{ Total } & 31 & 100 & & & & & & & & & & \\
\hline & $\mathrm{P}$ & & \multicolumn{2}{|c|}{,738 } & \multicolumn{2}{|l|}{, $044 *$} & \multicolumn{2}{|c|}{,257 } & \multicolumn{2}{|c|}{, 132 } & \multicolumn{2}{|c|}{,216 } \\
\hline & $\mathrm{T}$ & & \multicolumn{2}{|c|}{235} & $-2,02 *$ & & \multicolumn{2}{|c|}{$-1,13$} & \multicolumn{2}{|c|}{$-1,50$} & \multicolumn{2}{|c|}{$-1,23$} \\
\hline
\end{tabular}

As seen in Table 1; In the gender variable, the average value of wage system sub-dimension of satisfaction level of the HRM applications was found to be higher in male employees (2.51) than in female employees (2.29), and this change was found to be statistically significant $(\mathrm{p}<0.05)$. In the other sub-dimensions of HRM applications, no statistically significant difference was observed according to gender.

Table 2. The Perceived Organizational Support Variances According to Gender Variable

\begin{tabular}{lcccc}
\hline & & & & Perceived Organizational Support \\
Gender & $\mathrm{n}$ & $\%$ & $\overline{\mathrm{x}}$ & $\mathrm{ss}$ \\
\hline Female & & & 3,15 &, 809 \\
\hline Male & 98 & 30.5 & 3,11 &, 791 \\
\hline Total & 223 & 69.5 & &, 694 \\
\hline & 321 & 100 & &, 394 \\
\hline
\end{tabular}

As seen in Table 2, it was statistically found that perceived organizational support level did not show a significant difference according to gender group ( $\mathrm{p}>0.05)$. 
Table 3. The Variances of the Satisfaction Level of HRM Applications According to Working Year Variable

\begin{tabular}{|c|c|c|c|c|c|c|c|c|c|c|c|c|}
\hline \multirow{2}{*}{$\begin{array}{l}\text { Working } \\
\text { Year }\end{array}$} & \multirow[t]{2}{*}{$\mathrm{n}$} & \multirow[t]{2}{*}{$\%$} & \multicolumn{2}{|c|}{ Rewarding } & \multicolumn{2}{|c|}{ Wage System } & \multicolumn{2}{|c|}{ Career System } & \multicolumn{2}{|c|}{$\begin{array}{l}\text { Training Ptactices } \\
\text { and Performance }\end{array}$} & \multicolumn{2}{|c|}{$\begin{array}{c}\text { Communication with } \\
\text { Employee }\end{array}$} \\
\hline & & & $\overline{\mathrm{x}}$ & ss & $\overline{\mathrm{x}}$ & ss & $\overline{\mathrm{x}}$ & ss & $\overline{\mathrm{x}}$ & Ss & $\overline{\mathrm{x}}$ & ss \\
\hline $1-3$ years & 98 & 30.5 & 2,34 & 1,01 & 2,46 & ,947 & 2,71 & ,999 & $3,03^{\mathrm{a}}$ & ,612 & 2,42 & 1,05 \\
\hline 4-6 years & 114 & 35.5 & 2,09 & ,88 & 2,32 & ,832 & $2,46^{\mathrm{b}}$ & ,760 & $2,69^{b}$ & ,633 & $2,03^{\mathrm{b}}$ & 87 \\
\hline $7-9$ years & 45 & 14.0 & 2,16 & ,98 & 2,40 & ,951 & 2,61 & ,999 & 2,96 & ,797 & 2,32 & 1,17 \\
\hline $\begin{array}{l}10-12 \\
\text { years }\end{array}$ & 23 & 7.2 & 2,58 & 1,01 & 2,72 & 941 & $3,12^{\mathrm{a}}$ & ,776 & 2,94 & ,512 & 2,76 & 1,19 \\
\hline $\begin{array}{l}13 \text { years an } \\
\text { over }\end{array}$ & 41 & 12.8 & 2,44 & 1,02 & 2,64 & ,876 & 2,81 & ,823 & 2,94 & ,755 & $2,79^{\mathrm{a}}$ & 1,09 \\
\hline & $\mathrm{p}$ & & \multicolumn{2}{|c|}{,077 } & \multicolumn{2}{|c|}{,174 } & \multicolumn{2}{|c|}{,010* } & \multicolumn{2}{|c|}{,004* } & \multicolumn{2}{|c|}{, $000^{*}$} \\
\hline & $\mathrm{f}$ & & \multicolumn{2}{|c|}{2,13} & \multicolumn{2}{|c|}{1,60} & \multicolumn{2}{|c|}{3,38} & \multicolumn{2}{|l|}{3,90} & \multicolumn{2}{|c|}{5,64} \\
\hline
\end{tabular}

As it can be seen from Table 3, the satisfaction level of career system application was found to be higher in employees who had 10-12 years work experience (3.12) than those who had 4-6 years work experience (2.46) and this change was found to be statistically significant $(\mathrm{p}<0.05)$. It was found that the satisfaction level of training practices and performance evaluation practice were significantly higher in employees who had 1-3 years work experience (3.03) than those who had 4-6 years work experience (2.69) ( $\mathrm{p}<0.05)$. It was found that the satisfaction level of communication application with employee was higher in employees who had 13 years and over work experience and (2.79) than those who had 4-6 years work experience (2.03) and this change was statistically significant ( $\mathrm{p}<0.05)$.

Table 4. The Perceived Organizational Support Variances According to Working Year Variable

\begin{tabular}{|c|c|c|c|c|}
\hline \multirow{2}{*}{ Working Year } & \multirow{2}{*}{$\mathrm{n}$} & \multirow{2}{*}{$\%$} & \multicolumn{2}{|c|}{ Perceived Organizational Support } \\
\hline & & & $\overline{\mathrm{x}}$ & ss \\
\hline $1-3$ years & 98 & 30.5 & 3,16 & ,799 \\
\hline 4-6 years & 114 & 35.5 & 3,04 &, 764 \\
\hline $7-9$ years & 45 & 14.0 & 3,04 & ,927 \\
\hline 10-12 years & 23 & 7.2 & 3,35 &, 825 \\
\hline 13 years and over & 41 & 12.8 & 3,26 & ,683 \\
\hline Total & 321 & 100 & 3,13 &, 796 \\
\hline \multicolumn{3}{|c|}{$\mathrm{p}$} & \multicolumn{2}{|r|}{,267 } \\
\hline \multicolumn{3}{|c|}{ f } & \multicolumn{2}{|r|}{1,30} \\
\hline
\end{tabular}

As seen in Table 4, it was statistically found that the perceived organizational support level did not show a significant difference according to the working year of the employees ( $\mathrm{p}>0.05)$.

Table 5. The Variances of the Satisfaction Level of HRM Applications According to Educational Level Variable

\begin{tabular}{|c|c|c|c|c|c|c|c|c|c|c|c|c|}
\hline \multirow[t]{2}{*}{ Education Level } & \multirow[t]{2}{*}{$\mathrm{n}$} & \multirow[t]{2}{*}{$\%$} & \multicolumn{2}{|c|}{ Rewarding } & \multicolumn{2}{|c|}{ Wage System } & \multicolumn{2}{|c|}{ Career System } & \multicolumn{2}{|c|}{$\begin{array}{l}\text { Training Practices } \\
\text { and Performance }\end{array}$} & \multicolumn{2}{|c|}{$\begin{array}{l}\text { Communication with } \\
\text { Employee }\end{array}$} \\
\hline & & & $\overline{\mathrm{x}}$ & ss & $\overline{\mathrm{x}}$ & SS & $\overline{\mathrm{x}}$ & SS & $\overline{\mathrm{x}}$ & SS & $\overline{\mathrm{x}}$ & SS \\
\hline $\begin{array}{l}\text { Primary } \\
\text { Education }\end{array}$ & 6 & 1.9 & $3,00^{\mathrm{a}}$ & 1,40 & 3,16 & ,995 & $3,73^{\mathrm{a}}$ &, 393 & $3,53^{\mathrm{a}}$ &, 786 & $3,50^{\mathrm{a}}$ & ,862 \\
\hline $\begin{array}{l}\text { Secondary } \\
\text { Education }\end{array}$ & 5 & 1.6 & 2,36 & ,909 & 2,55 & ,925 & 2,52 & 1,14 & 2,60 & ,989 & 2,33 & 1,31 \\
\hline High School & 53 & 16.5 & $2,68^{\circ}$ & 965 & 2,58 & 1,05 & $3,05^{\circ}$ &, 853 & $3,05^{\circ}$ &, 790 & 3,00 & 1,03 \\
\hline University & 226 & 70.4 & 2,20 & 951 & 2,42 & 869 & 2,58 & 890 & 2,87 &, 613 & $2,22^{\circ}$ & 987 \\
\hline Postgraduate & 31 & 9.7 & $1,79^{\circ}$ &, 773 & 2,22 &, 788 & $2,28^{\circ}$ &, 688 & $2,56^{\circ}$ &, 666 & $1,88^{\circ}$ & 1,00 \\
\hline Total $321 \quad 100$ & & & & & & & & & & & & \\
\hline $\mathrm{p}$ & & & $\frac{, 00}{56}$ & &, 133 & & & & & $*$ &, 00 & 030 \\
\hline
\end{tabular}

As it can be seen from Table 5, statistically significant differences were found in all applications of the satisfaction level of HRM applications except the wage system according to the education level of employees $(p<0.05)$. It was found that the satisfaction level of rewarding application was higher in educated employees (3.00) than high school (2.68) and postgraduate students (1.79). It was found out that the satisfaction level of career system application was higher in educated employees who are in primary education level (3.73) than high school (3.05) and postgraduate educated employees (2.28).Satisfaction level of training practices and performance evaluation practice was found to be higher in educated employees who are primary education level (3.53) than high school (3.05) and postgraduate educated 
employees (2.56). It was found that the satisfaction level communication application with employee was higher in educated employees who are in primary education level (3.50) than those in university (2.22) and postgraduate educated employees (1.88).

Table 6. The Perceived Orgazinational Support Variances According to Education Level Variable

\begin{tabular}{lcccc}
\hline Education level & $\mathrm{n}$ & $\%$ & \multicolumn{3}{c}{ Perceived Organizational Support } \\
\cline { 4 - 6 } & & & $\overline{\mathrm{x}}$ & \multicolumn{2}{c}{$\mathrm{ss}$} \\
\hline Primary Education & 6 & 1.9 & 3,50 &, 948 \\
\hline Secondary Education & 5 & 1.6 & 2,47 & 1,20 \\
\hline High School & 53 & 16.5 & $3,42^{\mathrm{a}}$ &, 688 \\
\hline University & 226 & 70.4 & 3,10 &, 790 \\
\hline Postgraduate & 31 & 9.7 & $2,84^{\mathrm{b}}$ &, 755 \\
\hline Total & 321 & 100 & 3,13 &, 796 \\
\hline $\mathrm{p}$ & $\mathrm{f}$ & \multicolumn{3}{c}{$4,202^{*}$} \\
\hline
\end{tabular}

As It can be seen in Table 6, the mean value of organizational support perception was found to be higher in educated employees who are in high school level (3.42) than in postgraduate educated employees (2.84) and this change was found to be statistically significant $(\mathrm{p}<0.05)$.

Table 7. The Variances of the Satisfaction Level of HRM Applications of the Employees According to Staff Type

\begin{tabular}{|c|c|c|c|c|c|c|c|c|c|c|c|c|}
\hline \multirow[t]{2}{*}{ Staff Type } & \multirow[t]{2}{*}{$\mathrm{n}$} & \multirow[t]{2}{*}{$\%$} & \multicolumn{2}{|c|}{ Rewarding } & \multicolumn{2}{|c|}{ Wage System } & \multicolumn{2}{|c|}{ Career System } & \multicolumn{2}{|c|}{$\begin{array}{c}\text { Training } \\
\text { Practices and } \\
\text { Performance }\end{array}$} & \multicolumn{2}{|c|}{$\begin{array}{c}\text { Communication with } \\
\text { Employee }\end{array}$} \\
\hline & & & $\overline{\mathrm{x}}$ & ss & $\overline{\mathrm{x}}$ & ss & $\overline{\mathrm{x}}$ & ss & $\overline{\mathrm{x}}$ & ss & $\overline{\mathrm{x}}$ & ss \\
\hline Worker & 47 & 14.6 & $2,66^{\mathrm{a}}$ & ,994 & 2,57 & 1,09 & 2,88 & ,995 & 3,10 & ,687 & $2,70^{\mathrm{a}}$ & 1,08 \\
\hline Officer & 110 & 34.3 & 2,18 & ,947 & 2,40 & ,858 & 2,62 & ,854 & 2,85 & ,741 & 2,28 & 1,09 \\
\hline Trainer & 78 & 24.3 & 2,25 & 1,00 & 2,40 & ,864 & 2,68 & ,932 & 2,73 & 659 & $2,44^{\mathrm{b}}$ & ,949 \\
\hline Expert & 38 & 11.8 & $1,87^{\mathrm{b}}$ & ,784 & 2,24 & ,783 & 2,38 & ,685 & 2,91 & ,583 & $1,83^{\mathrm{b}}$ & ,882 \\
\hline Manager & 16 & 5.0 & 2,18 &, 880 & 2,79 &, 817 & 2,61 & ,910 & 3,02 & ,531 & 2,25 & 1,13 \\
\hline Other & 32 & 10.0 & 2,42 & 1,02 & 2,57 & ,975 & 2,65 & ,980 & 2,93 & ,524 & 2,44 & 1,07 \\
\hline Total & 321 & 100 & & & & & & & & & & \\
\hline $\mathrm{P}$ & & & \multicolumn{2}{|c|}{, $007 *$} & \multicolumn{2}{|c|}{,279 } & \multicolumn{2}{|c|}{,226 } & \multicolumn{2}{|c|}{,068 } & \multicolumn{2}{|c|}{, $006^{*}$} \\
\hline $\mathrm{F}$ & & & & 3,24 & \multicolumn{2}{|c|}{1,26} & & & \multicolumn{2}{|c|}{2,07} & \multicolumn{2}{|c|}{3,30} \\
\hline
\end{tabular}

As it can be seen from Table 7, it was found that the rewarding and communication with employees of the satisfaction level of HRM applications showed a statistically significant difference according to the staff types of the employees ( $p$ $<0.05$ ).According to the results of multiple comparison test; it has emerged that the satisfaction level of the rewarding application was higher in the employees working in the status of worker (2.66) than the employees working in the status of expert (1.87), and the satisfaction level of the communication application with the employee was in the employees working in the status of worker (2.70) than the employees working in the status of trainer (2.44) and working in the status of expert. (1.83).

Table 8. The Perceived Organizational Support Variances of the Employees According to Staff Type

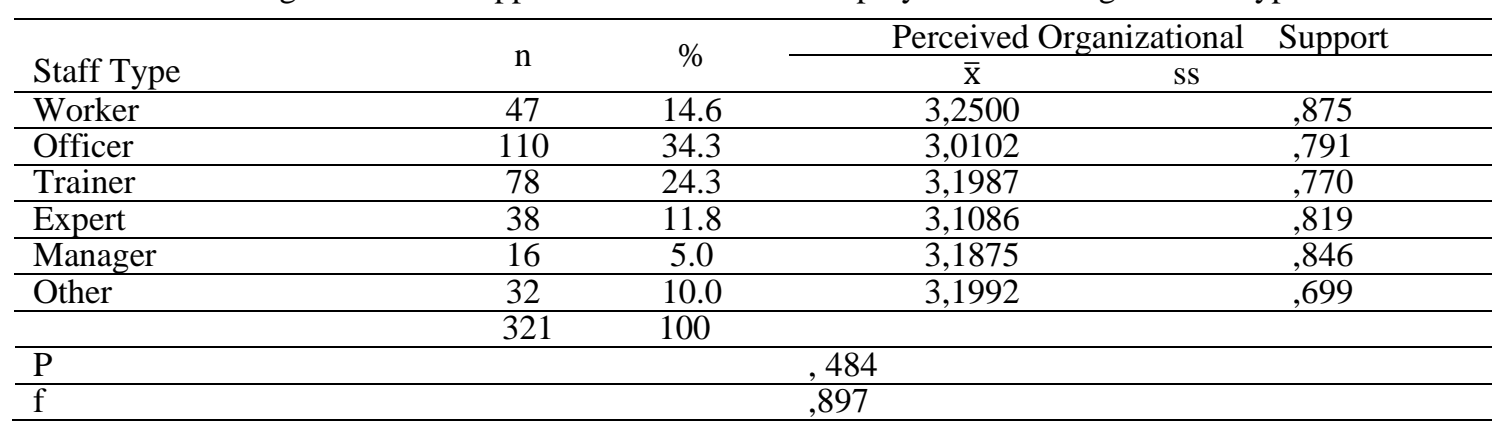


As seen in Table 8, it was statistically found that the perceived organizational support level did not show a significant difference according to the type of staff of the employees ( $p>0.05$ ).

Table 9. The Variances of the Satisfaction Level of HRM Applications of the Employees According to Age Groups

\begin{tabular}{|c|c|c|c|c|c|c|c|c|c|c|c|c|}
\hline \multirow[t]{2}{*}{$\begin{array}{l}\text { Age } \\
\text { Groups }\end{array}$} & \multirow[t]{2}{*}{$\mathrm{n}$} & \multirow[t]{2}{*}{$\%$} & \multicolumn{2}{|c|}{ Rewarding } & \multicolumn{2}{|c|}{ Wage System } & \multicolumn{2}{|c|}{ Career System } & \multicolumn{2}{|c|}{$\begin{array}{c}\text { Training } \\
\text { Practices } \\
\text { and } \\
\text { Performance }\end{array}$} & \multicolumn{2}{|c|}{$\begin{array}{c}\text { Communication with } \\
\text { Employee }\end{array}$} \\
\hline & & & $\overline{\mathrm{x}}$ & ss & $\overline{\mathrm{x}}$ & ss & $\overline{\mathrm{x}}$ & ss & $\overline{\mathrm{x}}$ & ss & $\overline{\mathrm{x}}$ & ss \\
\hline $18-25$ & 8 & 2,5 & 2,30 & 1,06 & 1,96 & 1,05 & 2,87 & 1,11 & 2,77 & ,433 & 2,37 & 1,16 \\
\hline $26-35$ & 178 & 55,5 & 2,16 & ,949 & 2,40 & 897 & $2,53^{\mathrm{b}}$ & 895 & 2,89 & ,667 & $2,16^{\mathrm{b}}$ & 1,00 \\
\hline $36-45$ & 95 & 29,6 & 2,32 & 1,02 & 2,44 & ,918 & 2,72 & ,865 & 2,82 & 649 & 2,41 & 1,03 \\
\hline $46-55$ & 34 & 10,6 & 2,57 & ,762 & 2,67 & ,721 & $3,01^{\mathrm{a}}$ & 669 & 2,92 & ,676 & $2,92^{\mathrm{a}}$ & ,984 \\
\hline $56-65$ & 6 & 1,9 & 2,30 & 1,58 & 2,95 & 1,28 & 2,80 & 1,61 & 3,53 & 1,19 & 3,16 & 1,72 \\
\hline Total & \multicolumn{12}{|c|}{321100} \\
\hline & $\mathrm{p}$ & & & 231 & & ,150 & &, $038^{*}$ & & & & ,001* \\
\hline & $\mathrm{f}$ & & & 40 & & 1,70 & & 2,56 & & & & 5,06 \\
\hline
\end{tabular}

As It can be seen in Table 9, it was found that the satisfaction level of HRM applications showed a statistically significant difference in career and communication applications according to age groups of the employees( $p<0.05)$. According to the results of multiple comparison test; it was found that the level of satisfaction of career application was higher in the employees working in the 46-55 age range (3.01) than those working in the 26-35 age range (2.53). It was found that the satisfaction level of communication application with employees was higher in the employees who are in the 46-55 age range (2.92) than those who are in the 26-35 age range (2.16).

Table 10. The Perceived Organizational Support Variances of the Employees According to Age Groups

\begin{tabular}{|c|c|c|c|c|}
\hline \multirow{2}{*}{ Age Groups } & \multirow{2}{*}{$\mathrm{n}$} & \multirow{2}{*}{$\%$} & \multicolumn{2}{|c|}{ Perceived Organizational Support } \\
\hline & & & $\overline{\mathrm{x}}$ & ss \\
\hline $18-25$ yaş & 8 & 2,5 & 3,12 & ,831 \\
\hline $26-35$ yaş & 178 & 55,5 & 3,08 & ,742 \\
\hline $36-45$ yaş & 95 & 29,6 & 3,11 & ,934 \\
\hline $46-55$ yaş & 34 & 10,6 & 3,28 & 462 \\
\hline \multirow[t]{2}{*}{$56-65$ yaş } & 6 & 1,9 & 3,68 & 1,291 \\
\hline & 100 & & & \\
\hline $\mathrm{p}$ & & & & \\
\hline f & & & & \\
\hline
\end{tabular}

As seen in Table 10, it was statistically found that perceived organizational support level did not show a significant difference according to age groups of the workers ( $p>0.05$ ).

Table 11. Correlation Analysis

\begin{tabular}{|c|c|c|c|c|c|c|}
\hline & 1 & 2 & 3 & 4 & 5 & 6 \\
\hline 1. Rewarding & 1 & & & & & \\
\hline 2. Wage System & $0.47 * *$ & 1 & & & & \\
\hline 3. Career System & $0.66 * *$ & $0.51 * *$ & 1 & & & \\
\hline $\begin{array}{l}\text { 4. Training Practices and Performance } \\
\text { Evaluation }\end{array}$ & $0.33 * *$ & $0.31 * *$ & $0.42 * *$ & 1 & & \\
\hline 5. Communication with Employee & $0.61 * *$ & $0.47 * *$ & $0.62 * *$ & $0.45 * *$ & 1 & \\
\hline 6. Perceived Organizational Support & $0.48 * *$ & $0.29 * *$ & $0.54 * *$ & $0.46 * *$ & $0.51 * *$ & 1 \\
\hline
\end{tabular}


Significant in the level of $* \mathrm{p}<0.05$, Significant in the level of $* * \mathrm{p}<0.01$.

According to the results of the correlation analysis between the five dimensions of satisfaction scale of HRM applications and organizational support, it was found that there were a statistically significant, moderate $(R=0.3-0.7)$ and positive relationship among all variables at $1 \%$ significance level. Accordingly, as the level of satisfaction of HRM applications increases, the level of perceived organizational support will increase.

\section{Discussion and Conclusion}

In order to determine the satisfaction level of the employers in sports organizations, according to the result of our study between 223 male and 98 female, there were found significant differences in the wage system application between female and male employees according to gender variable (Table 1). Although the difference in the average values was not large, it was statistically found that the satisfaction level of wage system application of male employees was higher than female employees. The same finding with our study has been reached by Kuzugüden (2011).The satisfaction of HRM applications of females according to wage system is significantly lower than male employees. In another study in the body of literature, there is a significant difference in perceptions of human resources practices regarding performance evaluation and wage factor depending on gender (Mutlu, 2016).Employees' perceptions regarding human resources management functions differ according to gender variable (Süer, 2017). It was found that the perception of competence of HRM applications of females was higher than males and there were significant differences between them (Aray, 2008). While internal relations and performance management applications and occupational safety applications which are among the sub-factors of human resources applications effectiveness do not differ according to gender, education and career planning applications vary according to gender (Demir, 2013). According to the results of the study of İpcioglu and Uysal (2009), there are no significant differences between HRM applications and in the terms of charging. When the perceptions of HRM applications of the employees were compared according to socio-demographic characteristics, no difference was found in the terms of gender (Berk, 2017). As it can be seen, there are different findings in the researches. The differences are thought to be caused by sample groups.

In our study, it was found that there was not much difference between the mean value of females and male employes in the perceived organizational support dimension in the gender variable, so that there were no significant differences between the genders (Table 2). There is information in the study generating the literature that supports our findings. In Erdem's (2014) study, there is no significant difference between the genders in perceived organizational support dimension. According to Yirci (2014), there is no evidence that gender variable makes a significant difference in organizational support perception in both foundation and state universities. No significant difference was found in the perception of organizational support of teachers working in primary schools in the terms of genders (Doğan, 2014; Derinbay, 2011; Ozek, 2016). There is no significant difference between perceived organizational support levels of civil servants and gender (Barutcu, 2015). When we look at the results of our research and research in the body of literature, we would like to report that we agree with Rhoades and Eisenberger's determination. Rhoades and Eisenberger (2002) state that gender is not related to perceived organizational support perception.

There were significant changes in the satisfaction level of HRM applications according to the working year variable (Table 3). The level of satisfaction of career system application has been found to be higher in the employees who had 10-12 years of work experience than those who had 4-6 years of work experience and it was determined that this change was statistically significant. It was found that the satisfaction level of training practices and performance evulation applications was significantly higher in the employees who had 1-3 years of work experince than those who had 4-6 years of work experince. It was determined that the satisfaction level of communication application with the employee was higher in the employees with 13 years and over working experience than the ones with 4-6 years of work experience and this change was statistically significant too Demir (2013). It has been reported that the employees who have been working in the organization for less than 1 year find training and career planning applications, internal relations and performance management practices that are the sub-factors of human resources applications effectiveness more effective than those who have been working for more than 15 years and there are significant differences between them. From the perspective of human resources, there is a significant difference according to the seniority in the study which investigates the factors affecting the job motivation of classroom teacher (Avşar, 2014). In the study where the performance evaluation system applied in the human resources management of the General Directorate of Sports was examined, it was found that there were significant differences in the duty period variable of the employees (Ilgar, 2014). When these results are taken into consideration, it can be said that the working year in organizations is effective in evaluating human resource management applications.

Another finding of our study is that perceived organizational support has the highest average values among the employees who have 10-12 years period of service; however, they did not show a significant difference in perceived organizational support dimension according to the working year (Table 4). The same finding with our study was reached 
by Gül (2010). In terms of period of service variable, perceptions of organizational support of teachers working in state and private high schools are not significantly different; however, organizational support perceptions of teachers with 12 and more years of service have the highest average score. Peterson (2015) in his study states that there is no significant relationship between perceived organizational support and period of service. The perception levels of organizational support of public sector employees do not show significant differences according to the working year (Barutcu, 2015). It is seen that teachers do not differ significantly in the perceptions of the organizational support regarding managerial and educational support in the schools they work for according to seniority variable (Özek, 2016). By looking at the results obtained, it can be considered that the duration of service does not have a significant effect on perceived organizational support.

It was found that the level of satisfaction of the HRM applications showed a statistically significant difference in all applications except the wage system according to the education level of the employees (Table 5).

It was found that satisfaction level of rewarding application was higher in the employees with primary education level than those with high school and postgraduate education. It was found out that the satisfaction level of the application of career system was higher among the employees with primary education level than those with high school and postgraduate education. Satisfaction level of educational applications and performance evaluation application was found to be higher in primary school educated employees than high school and postgraduate educated employees. It was found out that the satisfaction level of communication with employees was higher in those with primary school education than those with university and postgraduate education. There are similar findings with our study in the body of literature. According to the education variable, there is a significant difference between the primary education group and the master / doctorate group in the HRM applications of the workers (Mutlu, 2016; Berk, 2017; Ilgar, 2014). In a study where the effects of the perceptions of the information workers on human resources management applications on organizational commitment are investigated it was found that perceptions of evaluating performance of the information workers with postgraduate were significantly lower (Kuzugüden, 2011). It can be said that the satisfaction level of the employees who are primary school graduates is much more positive than high school and postgraduate graduates.

According to the education level variable of our study, in the perceived organizational support variances it was found that the average value of organizational support in high school educated employees was higher than the ones who have postgraduate education level and this change was statistically significant (Table 6). It can be said that the perceived organizational support of high school educated employees is more than the postgraduate educated employees. There are similar results with our findings in the body of literature. In the study conducted by Akalın (2006), it was stated that the perceived organizational support of the employees who are high school graduates was significantly higher than those who are university graduates. It was found that perceived organizational support level of the seafarers with high school education was higher than primary school graduates and there was a significant difference between them (Bozkurt, 2007). The levels of organizational support perception of public sector employees show significant differences according to their educational level (Barutcu, 2015; Eğriboyun, 2013). It has been determined that teachers differ significantly according to the educational background variable and teachers who are bachelor have more perception of organizational support than the ones who have associate degree and postgraduate degree (Doğan, 2014). It can be said that the level of education and the quality of education received are effective in the perceived organizational support changes of the employees.

It has been found that rewarding and communication with employees show a statistically significant difference according to the staff type of the employees of the level of satisfaction of HRM applications. It was found that the satisfaction level of rewarding application was higher in the employees working in the status of worker than the employees working in the expert status; the satisfaction level of communication application with the employees was higher in the employees working in the status of worker than the employees working in the status of trainer and expert (Table 7).

It can be said that the employees working in the status of worker are more satisfied with the rewarding and communication applications with the employees than the employees with other status. With the exception of training practices and performance practices of the employees working in the status of expert, it is remarkable that the scores they have from other applications are lower. It is seen that those who are in the executive position of the General Directorate of Youth and Sports generally can be effective through the use of all channels in the direction of the objectives of the communication in the organization and they mostly adopt the views of the that is beneficial to establish good relations with employees by using appropriate methods (Yetim et al., 1998). In the comparison made according to occupational classes, the perceptions of HRM related to HRM dimensions which are education and development, wage and reward system, working and physical conditions differ from according to occupational characteristics. It was found that the perceptions of those who have managerial duties related to their HRM applications were more positive than those who do not have (Berk, 2017). It was seen that individuals' perspectives on ethical issues 
differed in terms of the positions of workers (Sündük, 2014). It is thought that it is natural to experience differences in the level of satisfaction of the HRM applications of due to the staff they employ.

Another finding of our study is that the perceived organizational support levels of employees do not show a significant difference according to staff. As well as the means of organizational support perception of the employees are very close to each other, while the employees with the status of worker have the highest average, and the employees with the status of civil servant have the lowest (Table 8). In Akaln's (2006) study, there is no significant difference in the organizational support levels perceived by employees according to their duties and titles. There is no evidence to suggest that organizational support perception varies according to academic title (Yirci, 2014). It was determined that there was no statistically significant relationship between occupational categories and perceived organizational support levels (Bozkurt, 2007; Yoon \& Thye, 2002).

It has been found that the level of satisfaction of the HRM applications shows a statistically significant difference in career and communication application with employees according to their age groups. It was found that the satisfaction level of career application was higher in the employs with 46-55 age range than the ones with 26-35 age range; In the employees who are in the 46-55 age range, it was found that the satisfaction level of communication application with the employee was higher than the ones with 26-35 age range (Table 9).Training and career planning practices, in-house relations and performance management applications, which are among the sub-factors of human resources applications effectiveness, differ according to age groups. Employees in the 25-29 age range find training and career planning practices more effective than those in the 40-44 age range. Employees in the 18-24 age range find in-house relations and performance management applications more effective than those in the 35-39 age range (Demir, 2013). It was observed that there were significant differences between the 26-35 age group and the 36-45 age group in the HRM applications (Mutlu, 2016).

When the perceptions of HRM applications of the employees were compared according to age distribution, While the perception of HRM applications as a whole was significantly higher in the 18-25 age group than employees over the age of 41, In the comparisons made with the sub-dimensions of HRM, it is observed that the perceptions of activities of finding employees, wage and reward system, performance evaluation, career system and innovation activities differ according to age groups; in general, it is determined that young workers in the 18-25 age group have a more positive perception about their HRM dimensions than older workers (Berk, 2017). Significant differences were found between the perceptions of HRM applications of the employees and career system according to age groups. The average of career system perception of 26-40 age group employees are significantly lower than other groups (Kuzugüden, 2011). In the study where the effects of HRM applications on the performance of employees were examined, there were significant differences in terms of HRM applications and age variable (Kaya \& Kesen, 2014). There are significant differences in levels of employees' perception of HRM applications, positive psychological capital and work commitment depending on their age (Aybas, 2014). In the light of these findings, it is possible to say that age factor is an important factor in HRM applications.

Our last finding of demographic variables is that perceived organizational support level does not show a significant difference according to age groups of the employees (Table 10). While the employees in 56-65 age group have the highest average value, the lowest value belongs to the employees in 26-35 age group. According to Rhoades and Eisenberger (2002), there is a small positive relationship between perceived organizational support and age. It was found that there was no statistically significant relationship between seafarers' age groups and perceived organizational support levels (Bozkurt, 2007). No significant relationship was found between the age of administrators and teachers and their perceptions of organizational support (Eğriboyun, 2013). There was no significant relationship between age difference and perceived organizational support (Erdem, 2014). It can be said that perceived organizational support level does not cause significant differences according to age.

According to the results of the correlation analysis which was made between the five dimensions of satisfaction scale of HRM applications and organizational support, it was found that there were statistically significant, intermediate $(\mathrm{R}=$ $0.3-0.7$ ) and positive relationship among all variables at $1 \%$ significance level (Table 11). Accordingly, as the level of satisfaction of HRM applications increases, the level of perceived organizational support will increase.

As a result; In the body of literature, it was found that the studies on human resources management applications in sports organizations and perceived organizational support were quite limited; there were significantly differences in the level of satisfaction of HRM applications of the employees working in the provincial directorates of sports according to gender, working year, staff type, age category and educational level; while there was no significant difference in perceived organizational support according to gender, working year, staff type and age category, but there was a significant difference in education level; There were significant, moderate $(\mathrm{R}=0.3-0.7)$ and positively relationships between the two scales in terms of all variables. 
Findings and comments obtained from the research result are limited to the data obtained from a certain number of members in the sample. We believe that the researches that can be applied for the comparison of HRM applications applied in sport organizations which are active in both the private sector and public sector in Turkey will contribute to the related fields.

\section{References}

Akalın, Ç. (2006). Organizational based self-esteem as an intermediate variable and perceived organizational support of employees in the development of emotional organizational commitment. Unpublished Master's Thesis, Hacettepe University, Institute of Social Sciences, Ankara.

Aray, S. T. (2008). The effects of the perception of adequacy of human resource management practices on organizational commitment and intention to leave the organization. Unpublished $\mathrm{PhD}$ Disertation, Marmara University, Institute of Social Sciences, Istanbul.

Armeli, S., Eisenberger, R., Fasolo P., \& Lynch, P. (1998). Perceived organizational support and police performance: The moderating influence of socio motional needs. Journal of Applied Psychology, 83(2), 288-297. https://doi.org/10.1037/0021-9010.83.2.288

Avsar, F. (2014). The views of classroom teachers from the perspective of human resources on the factors affecting work motivation: An application in Çankaya district. Unpublished Master's Thesis, Çankaya University, Institute of Social Sciences, Ankara.

Aybas, M. (2014). The impact of human resources practices on the work commitment of employees and the mediating role of positive psychological capital, a research on the subject. Unpublished $\mathrm{PhD}$ Disertation, Istanbul University, Institute of Social Sciences, Istanbul.

Barutcu, K. (2015). A research aimed to determine the relationship of perceived organizational support in public personnel with organizational commitment and organizational identification levels. Unpublished Master's Thesis, Institute of Social Sciences, Eskisehir Osmangazi University, Eskisehir.

Berk, N. (2017). The effect of human resource management practices on organizational justice: The example of Sivas Sample Hospital. Unpublished Master's Thesis, Cumhuriyet University, Institute of Health Sciences, Sivas.

Bilir, F. P. (2005). Organizational climate of the General Directorate of Youth and Sports and perceptions of employees about participation. Unpublished PhD Disertation, Cukurova University, Institute of Health Sciences, Adana.

Bozkurt, F. (2007). A study on the relationship between demographic characteristics of seafarers working in maritime sector and organizational commitment, organizational citizenship behavior and perceived organizational support level. Unpublished Master's Thesis, Celal Bayar University, Institute of Social Sciences, Manisa.

Buluç, B. (1998). Basic components of human resource management in the information age. New Turkey Journal, 4(19), 781-788.

Çavuş, M. F., \& Develi, A. (2015). The effects of human resource management practices on organizational citizenship behavior. TISK Academy Journal, 10(20), 230-249.

Çolak, N. (2017). The relationship between perception of justice towards human resources functions and organizational culture Unpublished Master's Thesis, Istanbul University, Institute of Social Sciences, Istanbul.

Demir, İ. (2013). The effect of human resource management practices in the district municipalities operating within the boundaries of Istanbul Metropolitan Municipality on the work satisfaction of employes satisfaction. Unpublished Master's Thesis. Istanbul Aydın University, Institute of Social Sciences, Istanbul.

Derinbay, D. (2011). Perceived organizational support levels of teachers working in primary schools. Unpublished Master's Thesis, Pamukkale University, Institute of Social Sciences, Denizli.

Dogan, S. (2014). Perception of organizational support of teachers working in primary school (The Example of Polatlı district). Unpublished Master's Thesis, Hacettepe University, Institute of Educational Sciences, Ankara.

Dolaşır, S., Sunay, H., \& Imamoglu, A. F. (2002). Human Resources Management Mentality in Turkish Sports Management. Journal of Physical Education and Sport Sciences of Gazi University, 7(1), 40-55.

Eğriboyun, D. (2013). The relationship between organizational trust, organizational support and organizational commitment of administrators and teachers working in secondary schools (The Example of Bolu Province). Unpublished PhD Disertation, Abant Izzet Baysal University, Institute of Educational Sciences, Bolu.

Eisenberger, R., Hunting, R., Hutchison, S., \& Sowa, D. (1986). Perceived organizational support. Journal of Applied Psychology, 71(3), 500-507. https://doi.org/10.1037/0021-9010.71.3.500 
Erdem, H. (2014). The effects of perceived organizational support and locus of control on methods of coping with stress: The role of psychological capital in this process and a field study. Unpublished PhD Disertation, Inonu University, Institute of Social Sciences, Malatya.

Fişek, K. (1998). Sport Management in the terms of Government Policy and Social Structure Relations. Bağırgan Publishing House, 2nd Edition, Ankara. 230-241.

Gül, A. L. (2010). Organizational support according to high school teachers' perceptions (The Example of Ankara Province). Unpublished PhD Disertation, Hacettepe University, Institute of Educational Sciences, Ankara.

Gurbuz, S., \& Bekmezci, M. (2012). The role of mediating and regulating of emotional commitment on the impact of human resource management practices on information workers' intention to leave work. Istanbul University Journal of Faculty of Business, 41(2), 189-213.

Hakeem, I. A., \& Nisa, N. U. (2016). Perceived organizational support: A review on its antecedents and out comes. Abhinav International Monthly Refereed Journal of Research in Management \&Technology, 5(6), 30-38.

Huselid, M. (1995). The impact of human resource management practices on turnover, productivity, and corporate financial performance. Academy Of Management Journal, 38(3), 635-672. https://doi.org/10.2307/256741

Ilgar, E. (2014). Performance evaluation in human resources management: A research on the General Directorate of Sports. Unpublished PhD Disertation, Gazi University, Institute of Health Sciences, Ankara.

Ipcioglu, I., \& Uysal, G. (2009). The relationship between human resource practices and emotional commitment: An analysis of the sales force of pharmaceutical companies. Grind Stone Industrial Relations and Human Resources Journal, 11(3), 131-148.

Kaya, N., \& Kesen, M. (2014). An empirical study to examine the impact of human resource management practices and organizational culture types on employee performance. Ekev Academy Journal, (58), 97-122.

Koca, H. (2008) .Human Resources Management. Hourglass publications, Istanbul.

Krishnan, J., \& Mary, S. (2012). Perceived organisational support-an overview on its antecedents and consequences. International Journal of Multidisciplinary Research, 2(4), 1-13.

Kuzugüden, Ö. (2011). The effect of perceptions of information workers on human resource management practices on organizational commitment. Unpublished Master's Thesis, Erciyes University, Institute of Social Sciences, Kayseri.

Kuzutürk, B. (2016). The impact of human resource management practices on organizational performance. Unpublished Master's Thesis, Baskent University, Institute of Social Sciences, Ankara.

Mutlu, S. K. (2016). An application for the perception of human resources management practices by employees and their relationship with organizational commitment. Unpublished Master's Thesis, Toros University, Institute of Social Sciences, Mersin.

Nayir, F. (2014). Short form validity and reliability study of perceived organizational support scale. Mehmet Akif Ersoy University, Journal of the Faculty of Education, (28), 89-106.

Nugroho, H. S. W. (2017). Perceived organizational support as a determinant of health information systems implementation. Dama International Journal of Researchers (DIJR), 2(2), 24-30.

Ozdevecioglu, M. (2003). A study to determine the relationship between perceived organizational support and organizational commitment. Dokuz Eylül University Journal of Faculty of Economics and Administrative Sciences, 18(2), 113-130.

Ozek, B. Y. (2016). The examination of the relationship between primary school teachers' perceived organizational support and organizational trust levels. Unpublished Master's Thesis, Gazi University, Institute of Educational Sciences, Ankara.

Pate, J. M., \& Beaumont, P. B. (2006). The European low cost airline industry: The interplay of business strategy and human resources. Europen Management Journal, 24(5), 322-329. https://doi.org/10.1016/j.emj.2006.07.003

Peterson, A. (2015). Organizational support and job satisfaction of frontline clinical managers: The mediating role of work engagement. Electronic Thesis and Dissertation Repository. Available at: http://ir.lib.uwo.ca/etd/2967

Rhoades, L., \& Eisenberger, R. (2002). Perceived organizational support: A review of the literature. Journal of Applied Psycology, 87(4), 698-714. https://doi.org/10.1037/0021-9010.87.4.698

Sökmen, A., Ekmekçioglu, E. B., \& Celik, K. (2015). Relationship between perceived organizational support, organizational identification and executive ethical behavior: A Study on research assistants. Journal of Business 
Research, 7(1), 125-14. https://doi.org/10.20491/isader.2015115755

Süer, İ. İ. (2017). A research on employee satisfaction of human resources management functions in public enterprises. The Example of Ankara Çankaya Municipality. Unpublished Master's Thesis, Baskent University, Institute of Social Sciences, Ankara.

Sunduk, A. (2014). A research on ethical perceptions in public institutions: The sample of tax offices. Unpublished Master's Thesis, Karabuk University, Institute of Social Sciences, Karabuk.

Turgut, H. (2014). The mediating role of intrapreneurship in the impact of perceived organizational support on business performance. Journal of Business Research, 6(3), 29-62. https://doi.org/10.20491/isader.2014315939

Üren, S. G., \& Çorbacioğlu, S. (2012). The effect of perceived organizational support on organizational commitment: An example of a company operating in the manufacturing sector. Gazi University Journal of the Faculty of Economics and Administrative Sciences, 14(1), 29-52.

Yetim, A., Imamoglu, A. P., \& Cimen, Z. (1998). The approaches adopted by sports managers in human relations. Gazi University, Journal of Physical Education and Sports Sciences, 3(3), 61-70.

Yirci, R. (2014). Comparison of the opinions of instructors in state and foundation universities on perceived organizational support, organizational commitment levels and privatization in higher education. Unpublished PhD Disertation, Firat University Institute of Educational Sciences, Elazig.

Yoon, J., \& Thye, S. R. (2002). A dual process model of organizational commitment: Job satisfaction and organizational support. Work and Occupations, 29(1), 97-124. https://doi.org/10.1177/0730888402029001005

\section{Copyrights}

Copyright for this article is retained by the author(s), with first publication rights granted to the journal.

This is an open-access article distributed under the terms and conditions of the Creative Commons Attribution license which permits unrestricted use, distribution, and reproduction in any medium, provided the original work is properly cited. 